\title{
APLIKASI MONITORING AKTIVITAS AKADEMIK MAHASISWA PROGRAM STUDI INFORMATIKA UNIVERSITAS XYZ BERBASIS ANDROID
}

\author{
Dyah Ayu Megawaty ${ }^{1}$, Mahdy Eka Putra ${ }^{2}$ \\ S1 Sistem Informasi ${ }^{1}$ (e.g. Universitas Teknokrat Indonesia) \\ S1 Informatika ${ }^{2}$ (e.g. Universitas Teknokrat Indonesia) \\ aygawa07@gmail.com¹,mahdyflash03@gmail.com²
}

Received: (Juni 2020)Accepted: (Juni 2020) Published: (Juni 2020)

\begin{abstract}
Monitoring is a form of monitoring of the process of gathering and analyzing information based on an activity with the aim to find out and evaluate and take action on the errors produced. The use of technology has been widely used and applied to devices that can be used easily as well as smartphones. Data from the Ministry of Communication and Information 2018, there are more than 100 million people using smartphones, so that it can be considered in the use of technology. The purpose of this study is to produce an academic monitoring application on XYZ university informatics students who actively participate in academic activities or academic activities that will be used by student guardians. Information provided for student guardians in academic monitoring applications includes payment information, course values, lecture information to thesis. Based on the test results obtained functionality aspect of $95.83 \%$ stated the suitability of the function of the system and usability aspect of $94.79 \%$ so that it can be concluded that it is feasible to be applied to help monitor on XYZ university informatics students.
\end{abstract}

Keywords: Monitoring, academic, functionality aspect, usability aspect, Information.

\begin{abstract}
Abstrak
Monitoring merupakan bentuk pemantauan dari proses pengumpulan dan analisis informasi berdasarkan suatu kegiatan dengan tujuan untuk mengetahui dan mengevaluasi serta mengambil tindakan atas kesalahan yang dihasilkan. Penggunaan teknologi telah banyak digunakan maupun diterapkan pada perangkat-perangkat yang mampu digunakan secara mudah seperti halnya smartphone. Data Kominfo 2018, ada lebih dari 100 juta orang mengunakan smartphone, sehingga hal tersebut dapat dijadikan pertimbangan dalam pemanfaatn teknologi. Tujuan dalam penelitian ini adalah menghasilkan sebuah aplikasi monitoring akademik pada mahasiswa informatika universitas XYZ yang aktif mengikuti kegiatan atau aktivitas akademik perkuliahan yang akan dimanfaatkan oleh wali mahasiswa. Informasi yang disedikan bagi wali mahasiswa dalam aplikasi monitoring akademik antara lain yaitu informasi pembayaran, nilai mata kuliah, informasi perkuliahan hingga skripsi. Berdasarkan hasil pengujian yang dilakukan didapat aspek functionality sebesar 95,83\% menyatakan kesesuaian fungsi pada sistem monitoring dan aspek usability sebesar 94,79\% sehingga dapat disimpulkan bahwa layak untuk diterapkan untuk membantu memonitoring mahasiswa Informatika pada Universitas XYZ.
\end{abstract}

Kata Kunci: akademik, aspek functionality, aspek usability, Informasi, Monitoring. 
To cite this article:

Dyah Ayu Megawaty, Mahdi Eka Putra. (2020). APLIKASI MONITORING AKTIVIT AS AKADEMIK MAHASISWA PROGRAM STUDI INFORMATIKA UNIVERSITAS XYZ BERBASIS ANDROID. Jurnal Informatika dan Rekayasa Perangkat Lunak, Vol(1), 6574.

\section{PENDAHULUAN}

Aplikasi pada dasarnya merupakan hasil dari proses pengembangan yang dilakukan menggunakan teknologi modern sehingga dapat dimanfaatkan dengan perangkat mobile, sehingga mempermudah proses pengelolaan maupun pemantauan suatu kegiatan. Aplikasi adalah sekumpulan elemen yang saling berinteraksi dan saling berkaitan antara satu dengan yang lain dalam melakukan suatu kegiatan secara bersama untuk mencapai tujuan tertentu (Yasin, dan Verdi, 2012). Pemanfaatan teknologi yang dikembangkan menggunakan android mampu mempermudah proses penyampaian informasi bagi pengguna secara mudah dan cepat yang dapat terkoneksi menggunakan jaringan internet. Pemilihan smartphone menggunakan platform berbasis Android untuk salah satu pengembangan aplikasi selain bersifat open source (Sulihati, \& Adriyani, 2016). Jumlah pengguna aktif smartphone di Indonesia lebih dari 100 juta orang di tahun 2018 (Kominfo, 2018). Monitoring adalah proses pengumpulan dan analisis informasi berdasarkan indikator yang ditetapkan secara sistemmatis dan kontinu tentang suatu kegiatan atau program sehingga mampu dilaksanakan tindakan koreksi untuk penyempurnaan kegiatan itu selanjutnya (Astutic, \& Susanto, 2013). Dari hasil wawancara yang dilakukan kepada orang tua mahasiswa, penulis mendapat hasil sebanyak $92 \%$ tanggapan orang tua mengatakan sulit mengetahui informasi terkait aktivitas akademik didalam kampus, seperti informasi pembayaran, informasi nilai atau informasi pembejaran terkecuali jika orang tua mendatangi kampus. Masalah berikutnya yang sering dikeluhkan orang tua mahasiswa adalah informasi pembayaran yang di sampaikan oleh mahasiswa kepada orang tua yang terkesan mendadak karena banyaknya orang tua yang tidak mengetahui informasi pembayaran setiap semesternya, sehingga orang tua mahasiswa sering menanyakan hal-hal seperti tanggal pembayaran, kegiatan praktek kerja, persyaratan kelulusan perkuliahan hingga kegiatan-kegiatan eksternal perkuliahan. Berdasarkan pemaparan tersebut perlu adanya rancang bangun aplikasi atau sistem yang mampu memberikan informasi dan juga sebagai media monitoring terhadap kegiatan mahasiswadengan memanfaatkan teknologi serta mudah di akses.

\section{TELAAH PUSTAKA MONITORING}

Monitoring adalah "Proses pengumpulan dan analisis informasi berdasarkan indikator yang ditetapkan secara sistem matis dan kontinu tentang suatu kegiatan atau program sehingga mampu dilaksanakan tindakan koreksi untuk penyempurnaan kegiatan itu selanjutnya" (Astutic \& Susanto, 2013).

Monitoring memiliki beberapa tujuan,yaitu:

1. Mengkaji apakah kegiatan monitoring yang telah direncanakan sesuai dengan rencana awal.

2. Mengamati dan memantau setiap aktivitas proses monitoring terhadap objek program.

3. Mengidentifikasi setiap permasalahan yang timbul supaya dapat teratasi dengan cepat.

Menyesuaikan kegiatan dengan lingkungan yang berubah tanpa menyimpang dari tujuan awal Melakukan penilaian dan manajemen apakah pola kerja yang digunakan sesuai dengan rencana dan mampu mencapai tujuan kegiatan.

\section{APLIKASI}

Aplikasi menurut (Yasin, 2012) yaitu "Aplikasi merupakan sekumpulan elemen yang saling berinteraksi dan saling berketerkaitan antara satu dengan yang lain dalam melakukan suatu kegiatan secara bersama untuk mencapai tujuan tertentu".

\section{METODE PENELITIAN}

Proses pengembangan system melalui tiga tahap berikut, yang pertama adalah tahap study literatur dengan menentukan spesifikasi kebutuhan sistem. Tahap kedua yaitu pengembangan dengan menggunakan pengembangan prototype maka sistem akan lebih cepat dan dapat disesuaikan dengan permintaan dan yang terakhir yaitu tahap evaluasi dengan melakukan pengujian sistem terlebih dahulu kemudian didapat hasil dan 
dapat di evaluasi. Tahapan penelitian ini juga merupakan pengembangan dari kerangka penelitian, dan terbagi lagi menjadi beberapa sub menu bagian. Kerangka penelitian dapat dilihat pada Gambar 1.1.

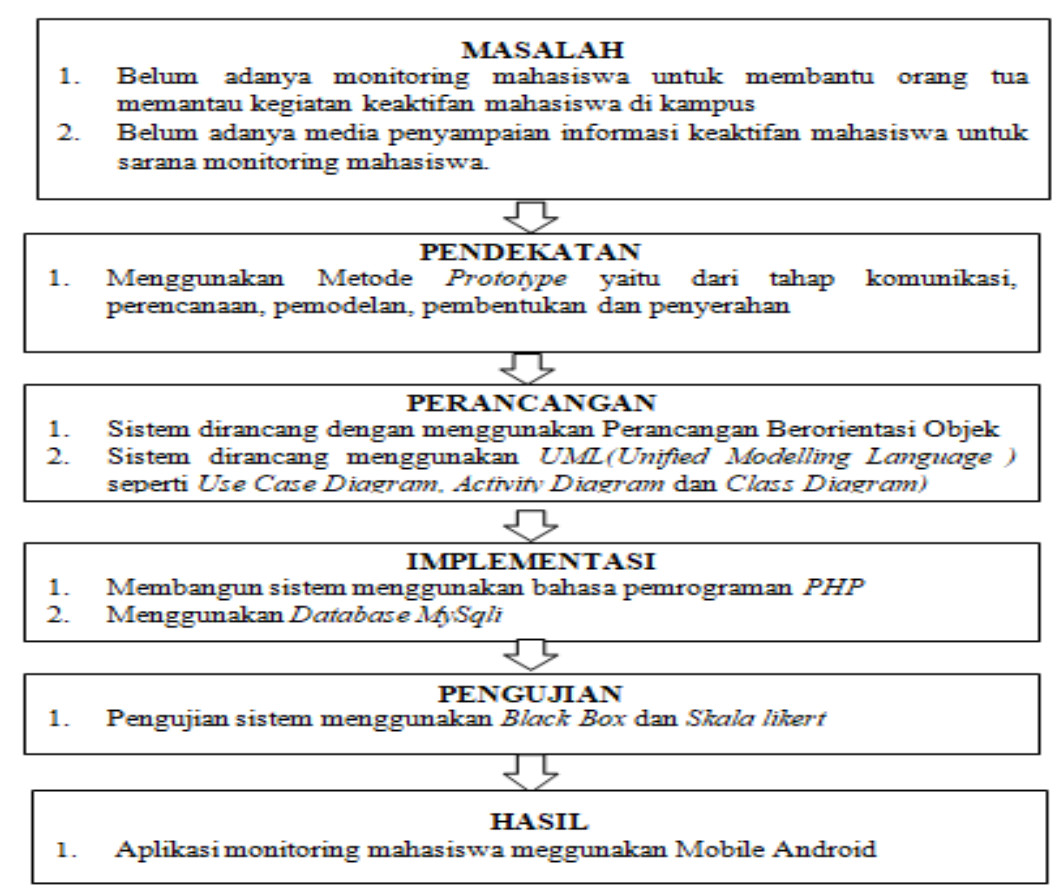

\section{Gambar 1. Tahapan Penelitian}

Dalam melakukan perancangan sistem yang akan dikembangkan dapat mengunakan metode prototype. Metode ini cocok digunakan untuk mengembangkan sebuah perangkat yang akan dikembangkan kembali. Metode ini dimulai dengan pengumpulan kebutuhan pengguna, dalam hal ini pengguna dari perangkat yang dikembangkan adalah peserta didik. Kemudian membuat sebuah rancangan kilat yang selanjutnya akan dievaluasi.

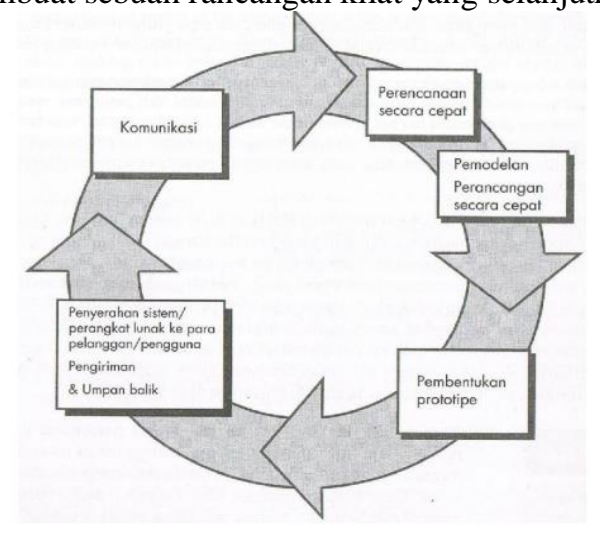

Gambar 2. Prototype

\section{Teknik Pengumpulan Data}

1. Wawancara (Interview)

Wawancara telah diakui sebagai teknik pengumpulan data atau fakta yang penting dan banyak dilakukan dalam pengembangan sistem informasi. Wawancara dilakukan dengan cara menanyakan pertanyaan secara langsung kepada pihak-pihak yang berkaitan untuk memperoleh informasi seperti data mahasiswa hingga data akademik kampusyang dilakukan pada bagian kampus dan pihak orang tua. Daftar pertanyaan dibuat dengan menggunakan metode Skala Likert (Yamin, Kurniawan, 2011) adalah penggukuran digunakan untuk mengukur sikap, pendapat, dan persepsi seseorang atau sekelompok orang 
tentang fenomena sosial. Dalam penelitian fenomena social ini telah ditetapkan secara spesifik oleh peneliti, yang selanjutnya disebut sebagai variable penelitian.

2. Dokumentasi

Dokumentasi dilakukan dengan mengumpulkan data yang bersumber dari data atau dokumen yang digunakan pada kampus seperti data combased, data nilai, data pembayaran dan data kelulusan.

3. Tinjauan Pustaka

Mempelajari kumpulan buku-buku yang dilakukan dengan cara membaca literatur-literatur dan tata bahasa yang baik yang ada kaitannya dengan data yang dibutuhkan, sehingga dapat menunjang proses penelitian seperti jurnal dan buku Pressman 2012 dan Rosa 2013.

\section{HASIL DAN PEMBAHASAN}

1. Implementasi Form Utama Orang Tua

Form utama orang tua merupakan tampilan yang digunakan untuk menampilkan data berupa mahasiswa, pembayaran hingga informasi akademik, berikut adalah form utama orang tua pada gambar dibawah ini :

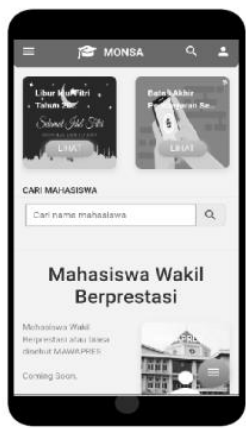

Gambar 3. Implementasi Form Utama Orang Tua

2. Implementasi Form Pencarian Mahasiswa

Form pencarian mahasiswa yang dilakukan oleh orang tua siswa dengan memasukan nama atau NPM mahasiswa sehingga akan muncul data nama mahasiswa yang terdaftar, berikut adalah form pencarian mahasiswa pada gambar dibawah ini :

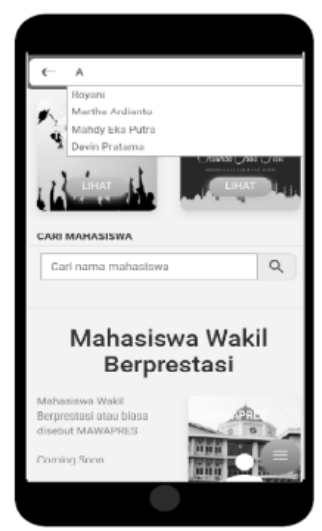

Gambar 4. Implementasi Form Pencarian Mahasiswa

3. Implementasi Form Detail Mahasiswa

Form detail mahasiswa merupakan tampilan yang digunakan untuk menampilkan profil mahasiswa secara jelas dengan menampilkan data angkatan, jurusan dan IPK, berikut adalah form detail mahasiswa pada gambar dibawah ini : 


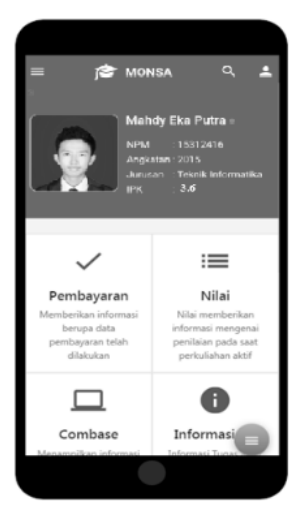

Gambar 5. Implementasi Form Detail Mahasiswa

4. Implementasi Form Detail Pembayaran

Form detail pembayaran merupakan tampilan yang digunakan untuk menampilkan informasi pembayaran dan status pembayaran yang telah dilakukan oleh mahasiswa, berikut adalah form detail pembayaran pada gambar dibawah ini :

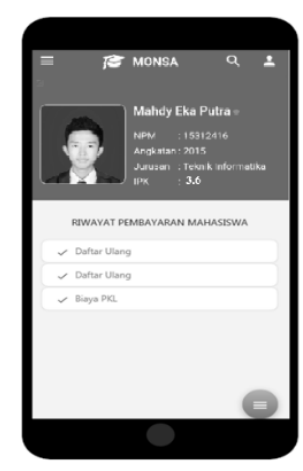

\section{Gambar 6. Implementasi Form Detail Pembayaran}

5. Implementasi Form Detail Nilai

Form detail nilai merupakan tampilan yang digunakan untuk menampilkan informasi nilai dan status nilai yang telah diikuti berdasarkan matakuliah yang telah diambil, berikut adalah form detail nilai pada gambar dibawah ini :

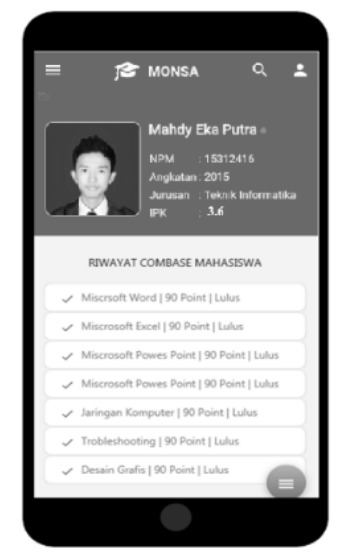

Gambar 6. Implementasi Form Detail Nilai 
6. Implementasi Form Detail Combased

Form detail combased merupakan tampilan yang digunakan untuk menampilkan informasi combased dan status combased yang telah diikuti berdasarkan matakuliah yang telah diambil, berikut adalah form detail combased pada gambar dibawah ini :

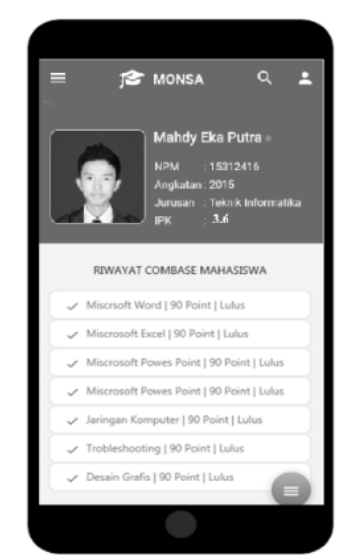

\section{Gambar 6. Implementasi Form Detail Combased}

7. Implementasi Form Detail Tugas Akhir

Form detail informasi tugas akhir merupakan tampilan yang digunakan untuk menampilkan informasi tugas akhir dan status tugas akhir yang telah diikuti dan diselesaikan, berikut adalah form detail informasi tugas akhir pada gambar dibawah ini :

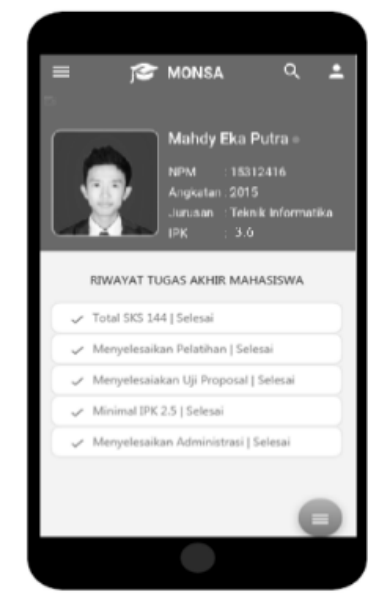

\section{Gambar 6. Implementasi Form Detail Tugas Akhir}

8. Implementasi Form Detail Informasi Akademik

Form detail informasi akademik merupakan tampilan yang digunakan untuk menampilkan informasi berupa informasi kegiatan perkuliahan maupun informasi pembayaran, berikut adalah form detail informasi akademik pada gambar dibawah ini : 


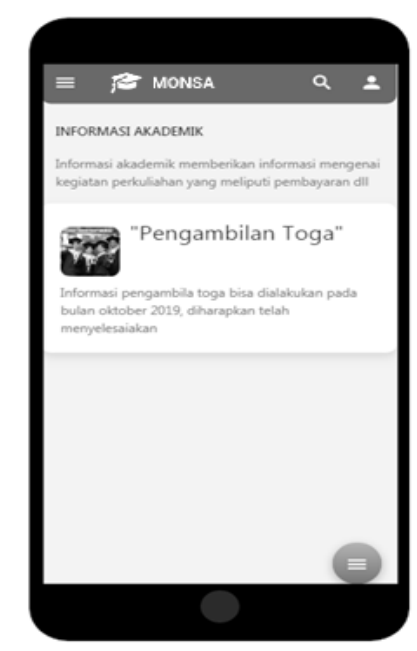

Gambar 6. Implementasi Form Detail Informasi Akademik

9. Implementasi Form Chat

Form chat merupakan tampilan yang digunakan untuk melakukan complain kepada admin mengenai informasi mahasiswa yang dapat digunakan oleh orang tua mahasiswa, berikut adalah form chat pada gambar dibawah ini :

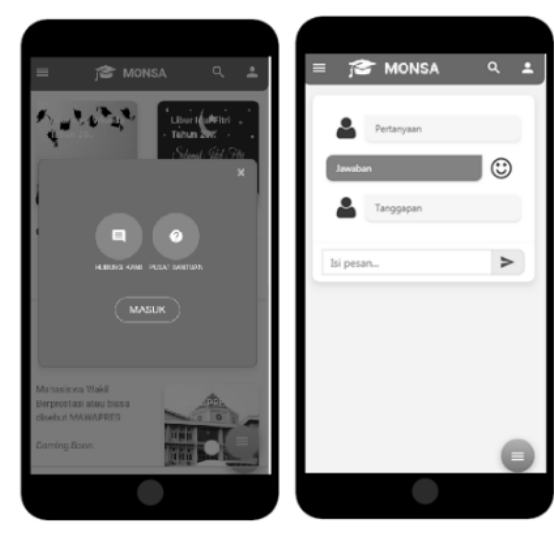

Gambar 6. Implementasi Form Chat

10. Implementasi Form Login

Form login merupakan tampilan yang digunakan sebagai sebagai hak akses kehalaman menu, berikut adalah tampilan login pada gambar dibawah ini :

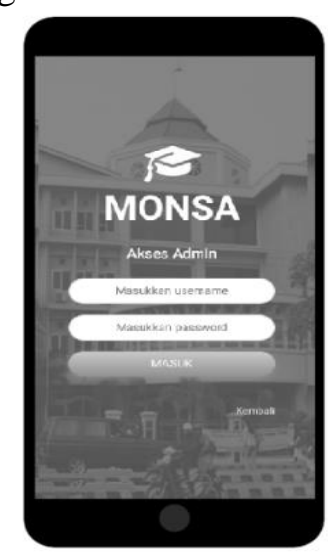

Gambar 6. Implementasi Form Login 


\section{PENGUJIAN}

Pengujian program dilakukan setelah penulisan kode program. Pengujian program dilakukan untuk memeriksa dan memastikan bahwa komponen-komponen telah berfungsi sesuai dengan yang diharapkan. Pengujian perlu dilakukan untuk mencari kesalahan-kesalahan atau kelemahan-kelemahan yang mungkin masih terjadi. Pengujian program dilakukan secara menyeluruh, pada pengujian program masing-masing program yang telah berjalan dengan benar dan baik bukan berarti program tersebut juga akan dapat berjalan dengan program lainnya dalam sistem dengan baik. Kumpulan dari semua program yang telah diintegrasikan perlu dites kembali untuk melihat apakah suatu program dapat menerima input data dengan baik, dapat memprosesnya dengan baik dan dapat memberikan output kepada program yang lainnya. Secara spesifik ada beberapa kegiatan terhadap pengujian antara lain yaitu pengujian functionality dan usability.

Tabel 1. Pengujian Functionality Admin

\begin{tabular}{|c|c|c|c|c|c|c|}
\hline Pertanyaan & Jawaban & Bobot & Frekuensi & Skor & Total skor & Max skor \\
\hline \multirow[t]{2}{*}{$x^{-2}$} & Ya & 1 & 1 & 1 & \multirow{2}{*}{1} & \multirow{2}{*}{1} \\
\hline & Tidak & 0 & 0 & 0 & & \\
\hline \multirow{2}{*}{2} & Ya & 1 & 1 & 1 & \multirow{2}{*}{1} & \multirow{2}{*}{1} \\
\hline & Tidak & 0 & 0 & 0 & & \\
\hline \multirow{2}{*}{3} & Ya & 1 & 1 & 1 & \multirow{2}{*}{1} & \multirow{2}{*}{1} \\
\hline & Tidak & 0 & 0 & 0 & & \\
\hline \multirow{2}{*}{4} & Ya & 1 & 1 & 1 & \multirow{2}{*}{1} & \multirow{2}{*}{1} \\
\hline & Tidak & 0 & 0 & 0 & & \\
\hline \multirow{2}{*}{5} & $\mathrm{Ya}$ & 1 & 1 & 1 & \multirow{2}{*}{1} & \multirow{2}{*}{1} \\
\hline & Tidak & 0 & 0 & 0 & & \\
\hline \multirow{2}{*}{6} & Ya & 1 & 1 & 1 & \multirow{2}{*}{1} & \multirow{2}{*}{1} \\
\hline & Tidak & 0 & 0 & 0 & & \\
\hline \multirow{2}{*}{7} & Ya & 1 & 1 & 1 & \multirow{2}{*}{1} & \multirow{2}{*}{1} \\
\hline & Tidak & 0 & 0 & 0 & & \\
\hline \multirow{2}{*}{8} & $\mathrm{Ya}$ & 1 & 1 & 1 & \multirow{2}{*}{1} & \multirow{2}{*}{1} \\
\hline & Tidak & 0 & 0 & 0 & & \\
\hline \multirow{2}{*}{9} & Ya & 1 & 1 & 1 & \multirow{2}{*}{1} & \multirow{2}{*}{1} \\
\hline & Tidak & 0 & 0 & 0 & & \\
\hline \multirow{2}{*}{10} & $\mathrm{Ya}$ & 1 & 0 & 0 & \multirow{2}{*}{0} & \multirow{2}{*}{1} \\
\hline & Tidak & 0 & 1 & 0 & & \\
\hline \multirow{2}{*}{11} & Ya & 1 & 1 & 1 & \multirow{2}{*}{1} & \multirow{2}{*}{1} \\
\hline & Tidak & 0 & 0 & 0 & & \\
\hline 12 & $\mathrm{Ya}$ & 1 & 1 & 1 & & \\
\hline 12 & Tidak & 0 & 0 & 0 & 1 & 1 \\
\hline Jumlah & & & & & 11 & 12 \\
\hline
\end{tabular}

Hasil $=(11 / 12) \times 100 \%=91,66 \%$

Tabel 2. Hasil Pengujian Functionality Orang Tua

\begin{tabular}{|c|c|c|c|c|c|c|}
\hline Pertanyaan & Jawaban & Bobot & Frekuensi & Skor & Total skor & Max skor \\
\hline \multirow{2}{*}{ 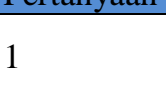 } & $\mathrm{Ya}$ & 1 & 1 & 1 & \multirow{2}{*}{ 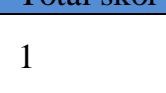 } & \multirow{2}{*}{ 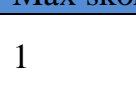 } \\
\hline & Tidak & 0 & 0 & 0 & & \\
\hline \multirow{2}{*}{2} & Ya & 1 & 1 & 1 & \multirow{2}{*}{1} & \multirow{2}{*}{1} \\
\hline & Tidak & 0 & 0 & 0 & & \\
\hline \multirow{2}{*}{3} & Ya & 1 & 1 & 1 & \multirow{2}{*}{1} & \multirow{2}{*}{1} \\
\hline & Tidak & 0 & 0 & 0 & & \\
\hline \multirow{2}{*}{4} & Ya & 1 & 1 & 1 & \multirow{2}{*}{1} & \multirow{2}{*}{1} \\
\hline & Tidak & 0 & 0 & 0 & & \\
\hline 5 & Ya & 1 & 1 & 1 & 1 & 1 \\
\hline
\end{tabular}


Jurnal Informatika dan Rekayasa Perangkat Lunak (JATIKA), Vol: 1, No: 1, 65-74

\begin{tabular}{|l|l|l|l|l|l|l|}
\hline & Tidak & 0 & 0 & 0 & & \\
\hline \multirow{2}{*}{6} & Ya & 1 & 1 & 1 & \multirow{2}{*}{1} \\
\cline { 2 - 7 } & Tidak & 0 & 0 & 0 & 1 & \multirow{2}{*}{6} \\
\hline \multicolumn{2}{|l|}{ Jumlah }
\end{tabular}

$$
\text { Hasil }=(6 / 6) \times 100 \%=100 \%
$$

Berdasarkan hasil pengujian yang dilakukan oleh admin dan orang tua makadidapat kesimpulan hasil yaitu $:$ Total $=(91,66 \%+100 \%) / 2=95,83 \%$.

Hasil implementasi yang dilakukan dengan penerapan black box testing dengan diuji berdasarkan functionality menghasilkan 95,83\% dengan hasil tersebut pengguna menyatakan kesesuaian fungsi pada sistem.

Tabel 3. Skor Jawaban Angket

\begin{tabular}{|c|c|c|c|c|c|c|}
\hline Pernyataan & Jawaban & Bobot & Frekuensi & Skor & $\begin{array}{l}\text { Skor } \\
\text { Total }\end{array}$ & Skor Max \\
\hline \multirow{4}{*}{1} & SS & 4 & 4 & 16 & \multirow{4}{*}{16} & \multirow{4}{*}{16} \\
\hline & $\mathrm{S}$ & 3 & 0 & 0 & & \\
\hline & KS & 2 & 0 & 0 & & \\
\hline & TS & 1 & 0 & 0 & & \\
\hline \multirow{4}{*}{2} & SS & 4 & 4 & 16 & \multirow{4}{*}{16} & \multirow{4}{*}{16} \\
\hline & S & 3 & 0 & 0 & & \\
\hline & KS & 2 & 0 & 0 & & \\
\hline & TS & 1 & 0 & 0 & & \\
\hline \multirow{4}{*}{3} & SS & 4 & 4 & 16 & \multirow{4}{*}{16} & \multirow{4}{*}{16} \\
\hline & $\begin{array}{l}S \\
\end{array}$ & 3 & 0 & 0 & & \\
\hline & KS & 2 & 0 & 0 & & \\
\hline & TS & 1 & 0 & 0 & & \\
\hline \multirow{4}{*}{4} & SS & 4 & 4 & 16 & \multirow{4}{*}{16} & \multirow{4}{*}{16} \\
\hline & $\mathrm{S}$ & 3 & 0 & 0 & & \\
\hline & $\mathrm{KS}$ & 2 & 0 & 0 & & \\
\hline & TS & 1 & 0 & 0 & & \\
\hline \multirow{4}{*}{5} & SS & 4 & 4 & 16 & \multirow{4}{*}{16} & \multirow{4}{*}{16} \\
\hline & $S$ & 3 & 0 & 0 & & \\
\hline & KS & 2 & 0 & 0 & & \\
\hline & TS & 1 & 0 & 0 & & \\
\hline \multirow{4}{*}{6} & SS & 4 & 3 & 12 & \multirow{4}{*}{14} & \multirow{4}{*}{16} \\
\hline & $\mathrm{S}$ & 3 & 0 & 0 & & \\
\hline & KS & 2 & 1 & 2 & & \\
\hline & TS & 1 & 0 & 0 & & \\
\hline \multirow{4}{*}{7} & SS & 4 & 4 & 16 & \multirow{4}{*}{16} & \multirow{4}{*}{16} \\
\hline & $S$ & 3 & 0 & 0 & & \\
\hline & KS & 2 & 0 & 0 & & \\
\hline & TS & 1 & 0 & 0 & & \\
\hline \multirow{4}{*}{8} & SS & 4 & 4 & 16 & \multirow{4}{*}{16} & \multirow{4}{*}{16} \\
\hline & $\mathrm{S}$ & 3 & 0 & 0 & & \\
\hline & KS & 2 & 0 & 0 & & \\
\hline & TS & 1 & 0 & 0 & & \\
\hline \multirow{4}{*}{9} & SS & 4 & 4 & 16 & \multirow{4}{*}{16} & \\
\hline & $\mathrm{S}$ & 3 & 0 & 0 & & 16 \\
\hline & KS & 2 & 0 & 0 & & \\
\hline & TS & 1 & 0 & 0 & & \\
\hline & SS & 4 & 4 & 16 & & \\
\hline 10 & $\mathrm{~S}$ & 3 & 0 & 0 & 16 & 16 \\
\hline & KS & 2 & 0 & 0 & & \\
\hline
\end{tabular}




\begin{tabular}{|c|c|c|c|c|c|c|}
\hline & TS & 1 & 0 & 0 & & \\
\hline \multirow{4}{*}{11} & $\mathrm{SS}$ & 4 & 0 & 0 & \multirow{4}{*}{12} & \multirow{4}{*}{16} \\
\hline & $\mathrm{S}$ & 3 & 4 & 12 & & \\
\hline & $\mathrm{KS}$ & 2 & 0 & 0 & & \\
\hline & $\mathrm{TS}$ & 1 & 0 & 0 & & \\
\hline \multirow{4}{*}{12} & SS & 4 & 0 & 0 & \multirow{4}{*}{12} & \multirow{4}{*}{16} \\
\hline & $S$ & 3 & 4 & 12 & & \\
\hline & $\mathrm{KS}$ & 2 & 0 & 0 & & \\
\hline & TS & 1 & 0 & 0 & & \\
\hline \multicolumn{5}{|c|}{ Jumlah } & 182 & 192 \\
\hline
\end{tabular}

Total $=(182 / 192) \times 100 \%=94,79 \%$

Berdasarkan perhitungan maka diperoleh persentase $94,79 \%$ dari pengujian usability. Dari skor persentase yang didapat maka kualitas perangkat lunak dari sisi usability telah sesuai dengan atribut usability atau bisa dikategorikan sebagian besar responden sangat setuju.

\section{SIMPULAN}

Berdasarkan uraian yang telah dijelaskan, kesimpulan dari penelitian ini yaitu:

1. Aplikasi monitoring mahasiswa dengan menggunakan media mobile android merupakan aplikasi yang mampu memberikan informasi secara rinci kepada orang tua mahasiswa ketika akan melihat keaktifan perkuliahan dan untuk mengetahui informasi berupa pembayaran hingga informasi akademik. Pentingnya penerapan monitoring sebagai bahan evaluasi yang dilakukan orang tua mahasiswa memerlukan penerapan dengan pemanfaatan media teknologi informasi dengan dirancang menggunakan metode pengembang sistem prototype, dimodelkan menggunakan UML seperi use case, activity dan class diagram, sehingga menghasilkan aplikasi yang bermanfaat bagi orang tua mahasiswa untuk mempermudah proses pemantauan.

2. Hasil implementasi yang dilakukan dengan penerapan black box testing dengan diuji berdasarkan functionality menghasilkan 95,83\% dengan hasil tersebut pengguna menyatakan kesesuaian fungsi pada sistem dan usability maka berdasarkan kuisioner yang dilakukan di dapat hasil yaitu sebesar 94,79\%, sehingga dapat disimpulkan bahwa aplikasi perlu dan layak untuk diterapkan.

\section{UCAPAN TERIMA KASIH}

Pada bagian ini, penulis menyampaikan ucapan terima kasihnya kepada sumber pendanaan atau bantuan yang diterima, dan pihak lain memainkan peran penting dalam melaksanakan studi Anda dan / atau menyiapkan naskah jika ada sebelum referensi.

\section{REFERENSI/DAFTAR PUSTAKA}

Astutic, \& Susanto. (2013). Sistem Monitoring Pendeteksi Komponen Kaleng Pecah.

Kominfo. (2018, 12 12). Pengguna Aktif Smartphone. Retrieved 03 20, 2019, from www.kominfo.go.id: www.kominfo.go.id Megawaty, Ayu, D dan Setiawan, E (2017). Analisis Perbandingan Social Commerce Dari Sudut Pengguna Website.

Lampung: Jurnal Teknoinfo. 11(1). pp: 10-13.

Pressman, R. S. (2012). Rekayasa Perangkat Lunak Edisi 7. Yogyakarta: Andi.

Pressman, R. S., \& Lowe, D. (2009). Web Engineering. Yogyakarta: Andi.

Priyanto, Nugroho, \& Widada. (2017). Sistem Informasi Monitoring Perkuliahan Berbasis Web.

Sulihati, \& Adriyani. (2016). Aplikasi Akademik Online Berbasis Mobile Android Pada Universitas Tama Jaga Karsa.

Sulistiawati, dan Sulistiani, H(2018). Perancangan Dashboard Interaktif Penjualan (Studi Kasus : PT Jaya Bakery ).

Lampung: Jurnal Teknokompak. 12(1). pp: 15-17.

Yamin, S., \& Kurniawan, H.,(2011) "Generasi Baru mengolah data Penelitiandengan PLS Path Modeling”, Jakarta, Salemba Infotek.

Yasin, Verdi. (2012). Rekayasa Perangkat Lunak Berorientasi Objek. Yogyakarta: Mitra Wacana Media. 